\title{
Using Group Drawings Activities to Facilitate the Understanding of the Systemic Aspects of Projects
}

\author{
João Alberto Arantes do Amaral \\ Prof., Federal University of São Paulo (UNIFESP), Brazil, joaoalberto.arantes@gmail.com
}

Aurélio Hess

Prof., University Oswaldo Cruz, Brazil, hessaurelio@gmail.com

Paulo Gonçalves

Prof., Università della Svizzera Italiana (USI), Switzerland,paulo.goncalves@usi.ch

\section{Vinícius Picanço Rodrigues}

PhD Researcher, Technical University of Denmark (DTU), Denmark, vipiro@dtu.dk

\begin{abstract}
In this article, we present our findings regarding promoting group drawing activities in order to facilitate the learning of systemic aspects of projects. We discuss the approach we used to engage the students and foster learning in our classes. We used group drawing activities in two project management undergraduate courses. The courses, which involved 41 students, took place during the second semester of 2016 in a public university in Brazil. We conducted qualitative research, using qualitative observation and focus group interviews. In order to gauge the effects of the use of this educational technique, we followed the five-phased qualitative analysis method, combined with a systems analysis of the data obtained from observation. Five recurrent themes emerged: 1) Making drawings in groups helps content retention and facilitates connections between the concepts explained by the professor; 2) Making drawings in groups promotes knowledge sharing among team members; 3) Making drawings in group fosters creativity and communication between students; 4) Drawing in groups reduces the students' boredom, makes the lecture more dynamic and interesting; 5) Drawing in groups reinforces bonds between students. Our systems analysis suggests that group drawing improves student participation in classroom activities, strengthens bonds between students, and enhances learning.
\end{abstract}

Key Words: group drawing, systems thinking, learning, project management, projectbased learning

\section{INTRODUCTION}

In this article, we discuss the use of group drawing in a project management course. We teach this course to undergraduate students in a public university in Brazil. The majority

Citation: Arantes do Amaral, J. A., Hess, S., Gonçalves, P \& Rodrigues, V. P. (2017). Using Group Drawings Activities to Facilitate the Understanding of the Systemic Aspects of Projects. International Journal of Instruction, 10(2), 3-22. https://doi.org/10.12973/iji.2017.1021a 
of our students have never taken a course in project management before. Many of them work during the day and attend courses at night. Others work in the morning and attend the classes in the evening. Since they come to class after working a busy day and often spending hours in traffic jams, they are generally tired and stressed. To make matters worse, the classrooms lack proper thermal and acoustic insulation: they are hot in the summer, cold in the winter, and always noisy. In short, we can say that our learning environment is far from ideal: we deal with stressed and tired students, many of whom do not have enough free time to study the concepts presented in classroom.

In order to mitigate these problems and to make the course more enjoyable and attractive, we follow a project-based learning approach. In the classroom, we make use of several teaching techniques that foster the participation and learning during class time. Outside the classroom, the students work in teams of five on different projects that lead to the creation of products or services for university partners.

The university partners are nine NGOs that help people in need, most from very poor communities. These organizations provide assistance to the following: 1) children who have been victims of sexual abuse, 2) orphans, 3) homeless people, 4) people with blindness, 5) children with special educational needs, 6) children with cancer, 7) hospitals, 8) leprosarium, and 9) university students from low-income backgrounds. Our students learn project management theory by accomplishing real projects that bring benefits to these people. We have been working with these institutions for several years in previous project management courses. Some NGOs came to us by recommendation of our alumni; others we invited to be our partners.

During our course, we schedule presentations on the status of each project to be held on specific dates. In these presentations, the students show us what they have accomplished so far: the project management tools they used, the plans they created and the results achieved. We thus provide students with a hands-on experience: the students to learn by doing, and share with the other students what they have learned.

However, one of the problems we face is that of making the students create connections between what is taught in class and what they experience in the real-life projects. We try to help students understand that the concepts they study separately in each class are indeed connected in a project. We struggle to make the students understand that a project is a system: the project management decisions they make may affect the project in different ways, leading to unexpected consequences.

In this article, we discuss our use of group drawing activities to facilitate the students' understanding of the systemic aspects of a project. Our study suggests that group drawing improves student participation in classroom activities, strengthens bonds between students, and enhances learning.

\section{REVIEW OF LITERATURE}

Drawings can be used to communicate concepts, ideas, opinions and beliefs. Drawings help us to comprehend concepts and to explain our ideas to others (Musgrove \& Musgrove, 2015). In addition, Roam (2013) argues that drawings can be valuable instruments for resolving problems since they can summarize and clarify complex 
abstract issues. Other researchers (Ainsworth et al., 2011; Musgrove, 2012) have noted that drawing can bring educational benefits, enhancing student engagement and improving learning.

Drawings can represent our interior images and perceptions of how the things are and how they are connected. These internal images and perceptions are called mental models (Cook \& Wind, 2006; Senge, 1990). In our courses, we challenge the students to draw in groups, in order to bring to the surface their mental models of the issues studied.

However, the mental models may have flaws: they may not be very helpful for anticipating the multiple feedback present in social systems: the delays, the nonlinearities, the unintended consequences of actions taken (Sterman, 1994).

Drawing in groups can help to reduce this problem, since the individual mental models can be brought the scrutiny of other people. Researchers (Chan, 2013) suggest that drawings can boost critical thinking and imagination. In addition to that, drawing in groups can improve group communication and collaboration (Tang, 1991).

A drawing can be a useful tool for representing systems. Systems are a group of components interconnected in order to accomplish a function or a purpose (Meadows \& Wright, 2008). Projects are systems: its components are the people and the resources involved. The purpose of projects is to create products or services (PMBoK, 2000).

Projects components are interconnected in intricate ways (Williams, 2002). There are several processes involved, including hiring, training, working and reworking on project's activities. These processes are dynamic; they change over time. To make the things even more complicated, projects may have multiple delays in each of these processes (Sterman, 1992). The project manager is the person responsible for making the project progress towards its goals. He or she uses his/her skills and knowledge in order to keep the project within the budget and on schedule (Gray \& Larson, 2002).

In our courses, we teach project management techniques. We follow a project-based learning approach, challenging the students to use project management techniques in real projects, with real clients. The use of project-based learning approach to teach project management skills has been used by scholars (Arantes do Amaral \& Matsusaki, 2016; Arantes do Amaral et al., 2015) in recent years.

One of the problems we have faced following this learning approach is that our students have limited time to assimilate the concepts and put them into practice. In order to facilitate their learning, we ask them to do some group drawing activities that we believe will help them to make connections between theory and practice. We challenge the students to work in groups to make drawings that represent projects and project management activities.

Although several articles have described the benefits of drawing in classroom activities, there remains a gap in the information regarding practical application of group drawing in a project-based learning course. In this article, we aim to address this issue.

\section{Research Questions}

1. What are the impacts of the use of group drawing activities on student participation? 
2. What are the impacts of the use of group drawing activities on student learning?

\section{METHOD}

\section{Research Design}

We followed a qualitative research approach, using qualitative observation and focus group interviews with four to six interviewees in each group. Qualitative observation and focus group interviews are two valid ways of collecting qualitative data usually used in qualitative studies (Creswell, 2013)

We decided to follow both approaches in order to obtain data from both the professor and the students.

The qualitative observation was accomplished by the first author (the course professor), who took field notes on the behavior of the groups while performing the activities. He also asked the participants open-ended questions during the activities in order to see how the activity was affecting their learning. For example, he asked questions such as "Is this drawing helping you to see the connections between the project manager actions and the consequences?"

The focus group interviews were accomplished by the students, with guidance from the professor. At the end of the drawing activities, the professor asked the students to do a 30-minutes focus group activity. He let the students know that data collected from this activity would be part of his research about the efficacy of the group drawing activities. $\mathrm{He}$ gave them detailed orientations of how this focus group should be accomplished. He explained the students should work together in groups, in order to answer a questionnaire with six-open ended questions. He asked to each group to choose one moderator. Then the professor gave to the moderators printed copies of the questionnaire and blank sheets of paper to collect the group's answers. The professor went over the questions with the students to make sure they understood them. After that, he explained that each moderator would have a pivotal role: he/she would lead the activity, reading aloud each question to the group and allowing the group members to present his/her answer to that question. The moderator would give five minutes to team members discuss their answers. After that, the moderator would write down the group response to the question, a response that all team members had agreed with. The group moderator would repeat this procedure with all remaining questions. After finishing the activity, the moderators would give the groups answers to the professor. The professor also let the students know that, during this activity he would leave the room, letting them to have complete freedom to express their thoughts.

\section{Population}

Forty-one undergraduate students in Economics and Accounting, aged from 19 to 22, participated in this research. All students were enrolled in two Project Management courses we taught during the first semester of 2016. The first course was taught in the afternoon, with 26 students organized in six project teams. The second course was taught the same day at night, with 15 students organized in three project teams.

Almost all students had no previous experience with project management. We chose to do the research with these students because of their lack of experience in project 
management theory and practice. We felt this would allow us to better ascertain whether the drawing activity was helping them make the connections between the theory presented in class and the projects they were working on.

\section{Research instrument}

Our research instruments were the field notes (created by the first author during the qualitative observation and questionnaire answered by each group of students during the focus group interviews.

\section{The field notes}

While the students were engaged in the drawing activity, the first author took short notes about the behavior of each group. We defined four variables to observe: participation, interest, learning, and group attitude. We graded on a scale of $1-3$.

Participation: this measures the students' participation in the group drawing activities.

1. Intense participation: The group is willing to participate in the activities, making efforts to collaborate in order to produce the best drawing they can. The group discusses each team member's ideas in detail.

2. Moderate participation: The group participates in order to fulfil the activity proposed, but without much commitment. A few students lead the activity; others collaborate without much interest.

3. Low participation: The group participation is poor; the students create the drawing only to meet the demands of the professor and make minimum efforts.

Interest: this measures the students' interest in the group drawing activities

1. High interest: the students are very curious about the activities proposed. They ask the professor several questions during the exercise, trying to figure out the best ways of solving the challenges proposed.

2. Medium interest: the students are moderately curious about the activities proposed. They ask few questions during the exercise.

3. Low interest: the students are indifferent to the activities proposed. They ask no questions during the exercise.

Learning: this measures how the students made connections between the subjects taught in previous classes and the real project activities.

1. High learning: the students are able to make several interesting connections between theory and practice. Their drawings capture many of the systemic aspects of the decisions they made in their real-life projects.

2. Medium learning: the students are able to make a few connections between theory and practice. Their drawings capture some of the systemic aspects of the decisions they made in their real-life projects.

3. Low learning: the students are not able to make connections between theory and practice. Their drawings do not capture any of the systemic aspects of the decisions they in their real-life projects.

Group attitude: it measures the attitude of students towards the group drawing activities. 
1. Humorous: the group work in a relaxed way. They make jokes and laugh during the activities, apparently having fun and enjoying the activities.

2. Stressed: the group works nervously, showing tension. They appear to be anxious during the activities.

3. Indifferent: the group works indifferently, and seems apathetic.

We designed these variables based on our experience on group behavior in previous courses. We decided to create a template (table 1) to help us to take quick notes during the group activities, so as not to intimidate the students.

Table 1

Example of one field note taken, using the template

\begin{tabular}{|c|c|c|c|c|}
\hline & Participation & Interest & Learning & Group attitude \\
\hline Group 8 & Intense & High & High & Humorous \\
\hline Observation & $\begin{array}{l}\text { Group perforn } \\
\text { the project as }\end{array}$ & $\begin{array}{l}\text { ry well. ' } \\
\text { game! }\end{array}$ & very is $\mathrm{i}$ & they represe \\
\hline
\end{tabular}

\section{The questionnaire}

The questionnaire had six open-ended questions, printed in a sheet paper that was deliver to each group moderator at the beginning of focus group activity. Two questions were related to the first research question (the impacts of the use of group drawing activities on students' participation) and three questions were related to the second research question (impacts of the use of group drawing activities on students' learning). The sixth question was an open-ended question, we asked the students to let us know what else they wanted us to know about grouping drawing activities.

Questions related to the first research question (the impacts of the use of group drawing activities on students' participation):

1. How do you feel about drawing in groups?

2. What would you prefer, a traditional class or a class with group drawing activities? Why?

We designed these questions because we wanted to know the students' reactions to the drawing activities. We wanted to know if they liked the activity or not, whether they felt the activity fostered participation and whether they might prefer a class that included this kind of activity to one that did not.

Questions related to the second research question (impacts of the use of group drawing activities on students' learning):

1. Please tell me if the group drawing activities helped to reinforce the contents of previous classes.

2. Please tell me if making the drawing made it easier to understand the systemic aspects of the project.

3. Please tell me your impressions of the drawings accomplished by the other groups.

We designed these questions because we wanted to know if the group drawing activities helped the students learn by reviewing and connecting the concepts. We also wanted to know what the students learned by analyzing the drawings made by the other groups. 


\section{Open-ended question}

1. What else would you like to tell us about the group drawing activity?

We designed this question in order to give the students freedom to say whatever they thought was relevant regarding the group drawing activity.

\section{Data analysis}

We analyzed the field notes applying descriptive statistics, measuring the variables of our observations. We analyzed the students' answers following the five-phased qualitative analysis method as proposed by Yin (2015): compile the database, disassemble the data, reassemble the data, interpret the data and conclude. First, we created our database by compiling the data from the written answers to the unstructured questionnaires. Then we broke the data into fragments of one sentence each. After that we reassembled the data, creating groups of similar/closely-related sentences. For each group, we created a title in the form of a sentence that summarized the main ideas of the group of similar sentences We called these recurrent themes. (Curry, 2016).

Then we interpreted the data, analyzing the connections between the recurrent themes and our field observations. This enabled us to assess the effectiveness of the group drawing activity from both the perspective of the students and that of the professors.

We accomplished this by means of a system analysis. A system analysis is the study of the systemic consequences and impacts of interventions (Arantes do Amaral, 2012). In our research, we wanted to understand how the actions taken during the group drawing activities had impacted the students' participation and the students' learning.

In order to perform a system analysis, we created a model of the dynamics of the group drawing activities performed in class (Figure 6), using a causal-loop diagram. The causal-loop diagram is composed of feedback loops. We were able to identify four feedback loops (three reinforcing loops and one self-correcting).

Each recurrent theme is represented in this model by means of a word or a set of words that synthetize the main ideas of the theme. We call this set of words system variables. For example, the recurrent theme "Making drawings in groups allows intense knowledge sharing among the team members" is represented by the system variable "knowledge sharing". Each system variable is a component of a feedback loop. Each system variable can influence or be influenced by other variables in the feedback loops. The discussion section of this article is based on the system analysis. The last phase the five-phased qualitative analysis, the conclusion, connects the findings with the research questions. The conclusion section of the article is based on the accomplishment of this phase.

\section{Procedure}

We introduce the group drawing activity at the end of the semester (in the 10th class), after the students have already studied the basic aspects of project management theory and are deeply involved in their own projects. We challenge them to create two different drawings: the first is designed to reveal the students' mental models of process management. The second aims to improve their mental models by stimulating reflection over a standard system dynamic model. 
The students' mental models are their internal images, their ingrained assumptions (Senge, 1990). Like all models, mental models are just simplifications of reality (Sterman, 2002). Mental models reflect the students' assumptions, conjectures and beliefs about the projects: what a project entails, how the activities are connected, and how the actions taken over the project impact the results (Stroh, 2015; Williams, 2002). However, sometimes the students' assumptions are wrong, since the projects are systems and systems behavior can be counterintuitive (Forrester, 1971).

The students are not conscious of their mental models (Senge, 1992). In our group drawing activities, we try to make the students aware of their mental models, by helping them to reveal them.

\section{Activity 1: Bringing to the Surface the Students' Mental Models}

First, we divide the class into groups by project. We then ask the students to create a drawing that represents everything that may happen in a project. Each group is challenged to work together, following these instructions:

1) The drawing should represent a visualization of the project's development, from conception to finalization.

2) The drawing may take any form: students can create a comic story, they can create flowcharts representing the phases of the projects, or they can create something else. They are free to use their imaginations.

3) Students should try to represent actions the project manager needs to take to avoid problems that may lead to the need to rework the project. These might include such actions as pressuring the team to work harder, hiring new people for the project, or even trying to postpone the delivery of the product or service.

4) The students should collaborate on the drawing: it should represent the ideas of the group, not the ideas of just one individual.

5) Students have 45 minutes to create the drawing. The groups are not allowed to see each other's' drawings during the creation process. After finishing the drawings, the groups should present their drawings to the class and explain them.

We give to each group a large blank paper in A1 format (841x $594 \mathrm{~mm}$ ), colored wax crayons and colored pens. The groups are asked to move to different positions in the classroom; some groups work in the corners of the room, others stay in the middle. Usually the students have a lot of fun during this activity: it is something that they are not used to doing in other undergraduate courses. While the group is working on their drawing, we take notes about the groups' behavior discreetly, doing our qualitative observation research.

At the end of the time given, each group presents its drawing to the class and discusses the logic of the drawing. We ask them to explain how they represented the way that the project unfolds and the decisions the project manager makes. We promote a discussion in order to bring to the surface their mental models. We do this in a very relaxed way, allowing the groups to compare the strengths and the weaknesses of each drawing. 


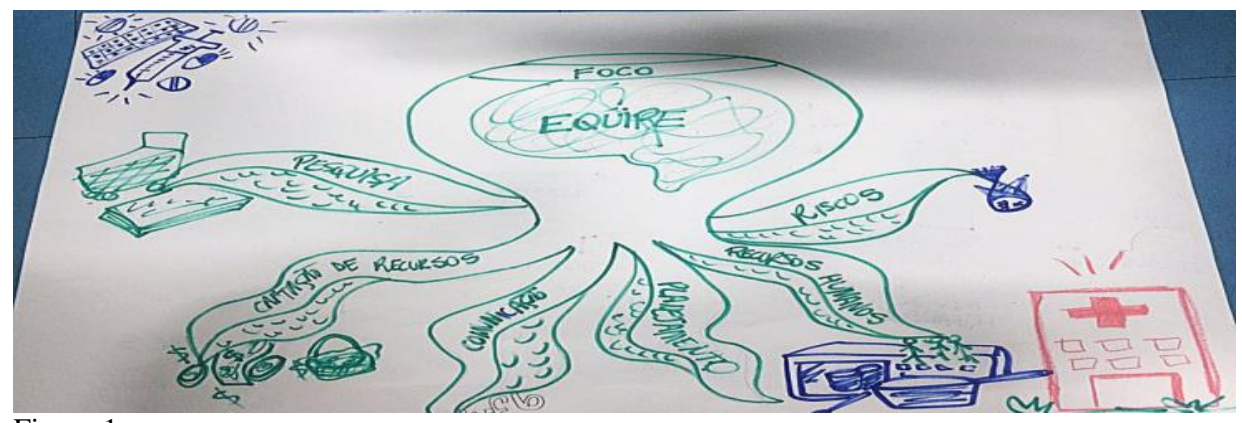

Figure 1

The group represented the project as an octopus

Figure 1 shows one group's drawing of a project that involved obtaining cooking implements for a hospital kitchen. The group represented the project as an octopus. The group explained that the brain of the octopus was the project team and each arm represented one important aspect of the project. For example, the first arm represented the project's risks, the second the human resources, the third the necessary planning, the fourth the communication that would take place within the project, the fifth the fundraising activities and sixth the project's scope. They explained that, like the octopus's arms, all aspects of the project were interconnected. They gave an example: "We have to plan the fundraising activities. If the planning is inadequate, we will not be able to get the resources to buy the cooking implements." We asked them "Why does this octopus have only six legs?" The class laughed when one student said that the two missing legs represented the project's problems and the mistakes that project manager usually makes.

Figure 2 represents a visualization of a generic project. The group represented the project as a board game. Their game had fifteen positions, to correspond to the fifteen weeks of the project's duration. Thus, each position represented one week of the project. They drew a question mark on the first position, representing the questions they had about the project's scope at the beginning. The students explained that they chose to represent the project as a board game because, like a game, a project has rules. If a team does something incorrectly, they have to come back and rework this part of the project. In a board game this is equivalent to being sent back several positions. They also said the board games usually have dice. Throwing the dice and getting a high number is good for a player. Getting a small number is bad. They said us that the project manager's decisions are similar to throwing dice in a game: there is always a risk involved in each decision, there is always a probability that something can go wrong or even go better than planned.

We asked them why the sixth, seventh and eighth positions on the board were bigger than the others and colored with brown crayon. They told us that the bigger boxes indicated the weeks they worked hard, doing several funding raising activities. According to them, these weeks seemed to last more than seven days. They told us the color was related to stress the team faced during those weeks. 


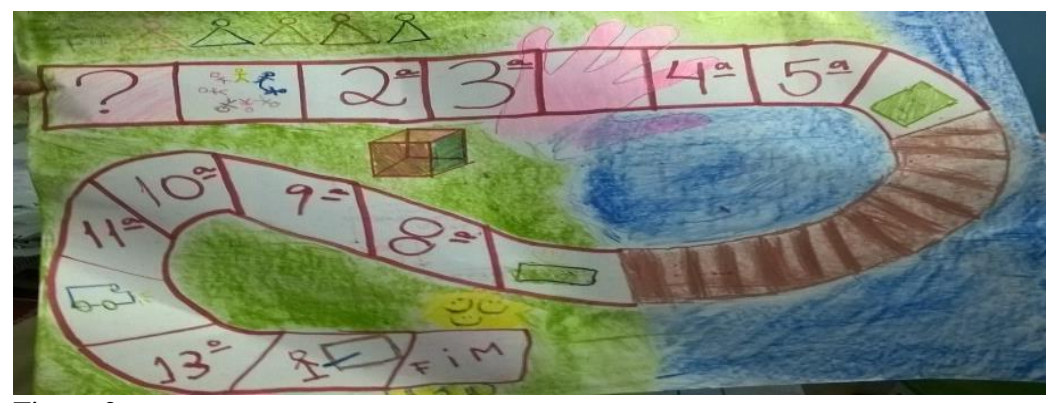

Figure 2

The group represented the project as a board game

As these examples show, these students were able to capture some of the project processes and characteristics; they were able to make connections between the theory they had studied and the project they were working with. They were able to see how one action undertaken during a project could affect another, and how there might be setbacks. However, most of their drawings failed to represent the actions that project manager usually takes and the consequences of these decisions to the project. In order to fill this gap, we performed a second activity.

Activity 2: Comparing the Students'Drawing with a System Dynamics Model

To begin, we elicit from the students what actions they think the project manager can take to control the project so that it finishes on time and stays within the budget. Then we ask them to think about the possible impacts of each action.

After that we invite the students to discuss, within their groups, the consequences of the three most common actions project managers take in order to control a project: 1) Pressure the team to work harder 2) Hire new people for the project 3) Postpone the delivery date of the product or service.

After this discussion, we give each group a stock and flow diagram that represents a generic model of how a project unfolds (Figure 3). We let them know that we were going to use this model as basis for this activity.

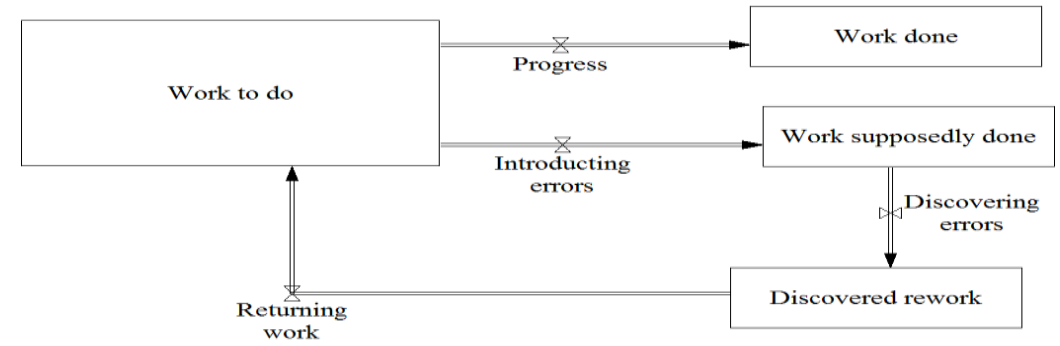

Figure 3

The project model given to students, based on a well-known project model, developed by Cooper (1980). This model was improved later by him (Cooper, 1993) and again by Lyneis and Ford (2007). 
We explain that the rectangles represent the stocks, the overlapped arrows represent the flows. We let them know that stocks represent things (material or immaterial) that accumulate over the time; the flows change the stocks, making them increase or decrease. We explain that when the project team works, it transforms the work to do into work done. However, sometimes the team may introduce errors. It takes time to discover these errors and rework the project.

We then ask the students to copy to the A1 paper the model we have given, and draw over it lines in different colors, representing the impacts of the three project manager actions. We give them more twenty minutes to do this. While the group is working on their new drawing we again discreetly take notes about the groups' behavior, completing our qualitative observation research.

The students then present their new drawings, explaining the connections they have created. Figure 4 is an example of their work. The different colors represent the different consequences of the project manager's actions.

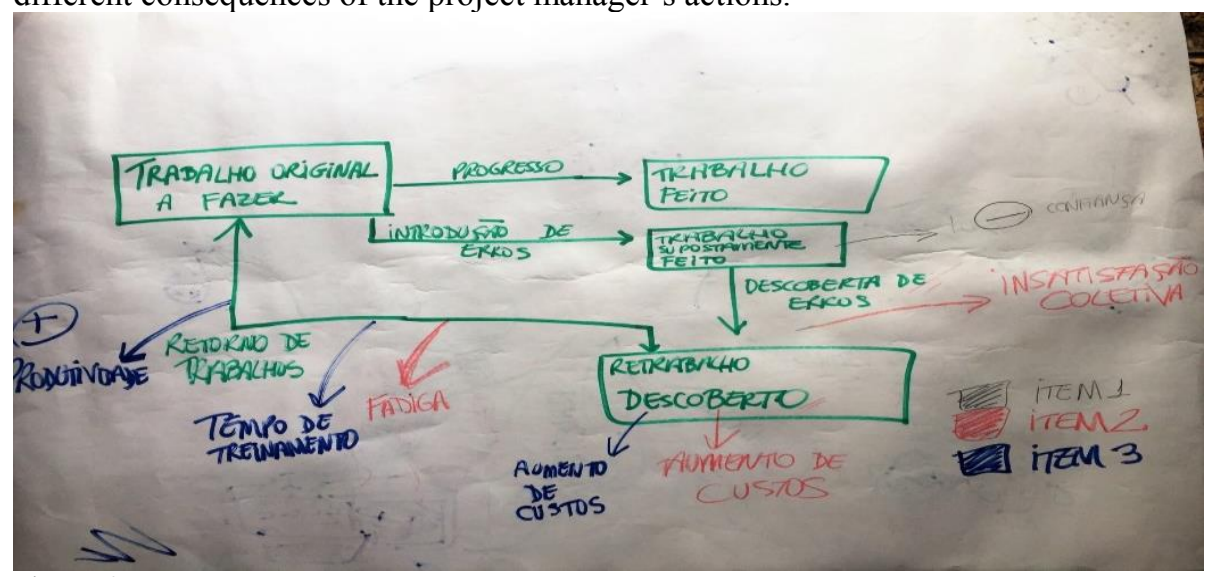

Figure 4

An example of the new drawing created by the students.

Next, we reflect together on the systemic aspects of the project manager's decisions, using as reference the article of Lyneis and Ford (2007), represented in Figure 5. This final model brings all the strands together, the ones that the students have discovered and others they have not.

We discuss the counter-intuitive effects of each of the actions the project manager takes. For example, we make students aware of the fact that if the project manager increases the pressure, the project may initially evolve more rapidly, but that fatigue may increase later. This fatigue may in turn lead to the introduction of errors, which can make the rework increase even more, eventually slowing the project and raising costs. After that, we conduct the focus group interviews, as described in Methods Section of this article. We wrap up the class by making connections between what they learned with their drawings and what they learned working with Lyneis and Ford's model. 


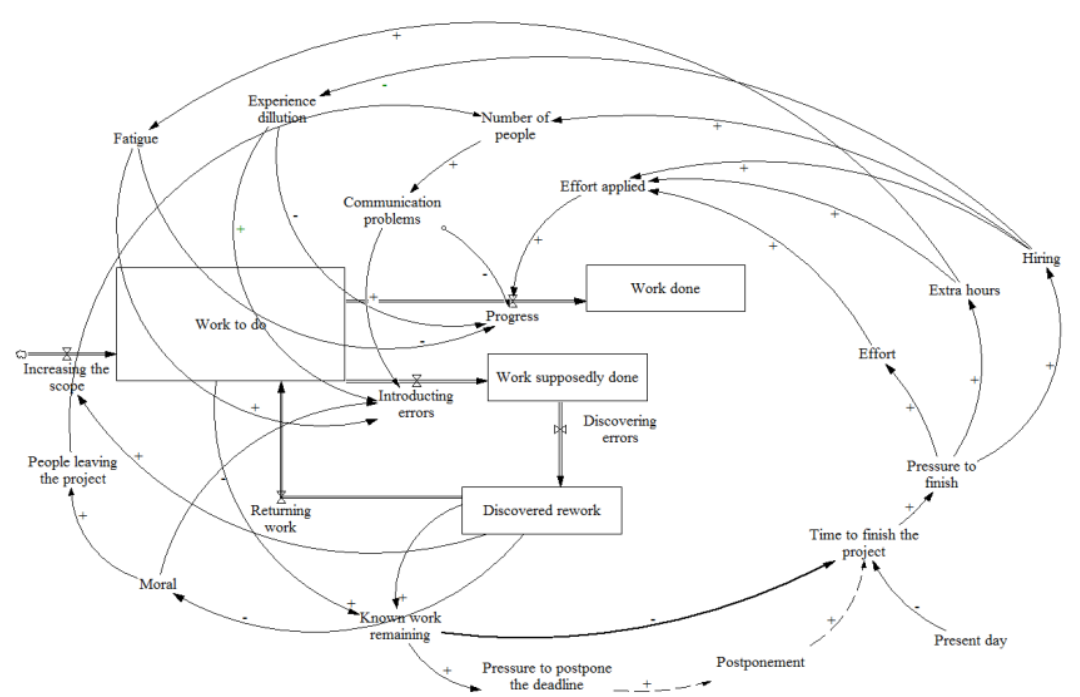

Figure 5

The figure used to discuss the systemic aspects of a project. Adapted from (Cooper, 1993; Lyneis $\&$ Ford, 2007)

\section{FINDINGS}

In this section, we present the results from the qualitative observation and from the questionnaires.

\section{Results from qualitative observation}

Our observation suggests (table 2) that $78 \%$ of the groups had intense participation, $11 \%$ participated in moderate way and $11 \%$ had low participation. Regarding interest, we find that $78 \%$ of the groups had high interest in the group drawing activity, $11 \%$ moderate interest and $11 \%$ low interest. Concerning the learning, we see that $56 \%$ of the groups experienced high learning, 33\% medium learning and $11 \%$ low learning. Finally, we can say that $78 \%$ of the groups maintained a humorous attitude, $22 \%$ behaved nervously, indicating stress and $11 \%$ were indifferent to the activities.

Table 2

The results from qualitative observation

\begin{tabular}{lllll}
\hline & Participation & Interest & Learning & Group attitude \\
\hline Group 1 & Intense & High & High & Humorous \\
\hline Group 2 & Intense & High & Medium & Humorous \\
\hline Group 3 & Moderate & Moderate & Medium & Stressed \\
\hline Group 4 & Intense & High & High & Humorous \\
\hline Group 5 & Low & Low & Low & Indifferent \\
\hline Group 6 & Intense & High & High & Stressed \\
\hline Group 7 & Intense & High & High & Humorous \\
\hline Group 8 & Intense & High & High & Humorous \\
\hline Group 9 & Intense & High & Medium & Humorous \\
\hline
\end{tabular}




\section{Results from questionnaires}

Five recurrent themes (RT) emerged from the analysis of the group answers to the unstructured questionnaires:

RT1: Making drawings in groups helps retention of content and helps students make connections between the concepts explained by the professor.

Students described that working in teams in group drawing activities, helped them to connect the diverse concepts presented in previous classes. They considered that the task of creating a drawing forced them to systematize the more important issues studied in previous classes. One student explained:

"Drawing helped us, in a funny way, to remember what we had learned. It helped us to make connections between the theoretical concepts, to see the big picture."

Another student stressed the reasoning involved in creating drawings:

"Creating drawings stimulates you to make the concepts simpler, more easily understandable. The drawing also helps to memorize the concepts."

RT2: Making drawings in groups allows intense knowledge sharing among the team members.

Students consider that making draws allows them to share knowledge in different ways.

One way is by learning from other team members. One student described how it worked:

"In order to make a drawing in a group we have to discuss the ideas of all the team members: we have to combine different points of view; we have to reach a consensus of opinion among us in order to create an interesting figure that represent our point of view."

Students also valued seeing the drawings of other teams. One student pointed to the importance of this:

"We were very impressed with the results of the other groups. The drawings were very elaborate, colourful and logical. It was a very enriching experience, since the groups present innovative solutions that we hadn't considered."

RT 3: Making drawings in groups is fun, fostering creativity and communication skills.

Almost all students wrote in their reports that drawing stimulated them to be creative. One student explained:

"We had an amazing time, lots of fun and laughs! Working in group in this activity allows us to be very creative."

In addition to that, the students pointed out that they had to make choices among different solutions to the challenge proposed. Therefore, they had to exercise their communication skills.

"The team members had different ideas of how the drawing should be. We spent a lot of time communicating, trying to sell our ideas to the other members of our teams." 
RT4: Drawing in groups reduces the student boredom, makes the lecture more dynamic and interesting.

The students consider that this activity brings energy to the class. According to one of them:

"The playful activities remove the tediousness. We move our bodies, we communicate with our colleagues. The activity is so intensive that we didn't see the time passing."

RT5: Drawing in groups helps students reinforce their bonds.

Students told us that the experience reinforced the connections between them. One student said:

"During this activity we had to interact with our colleagues and with the other groups. It contributed to improvement of our camaraderie, our mutual trust and friendship."

These five recurrent themes lead us to identify key system variables. These variables were used to create a system's model (Figure 6). Table 3 summarizes the results in a more structured way.

Table 3

The key system's variables.

\begin{tabular}{|c|c|}
\hline Recurrent themes & Key system's variables \\
\hline $\begin{array}{l}\text { RT 1: Making drawings in groups help content } \\
\text { retention and helps make connections between the } \\
\text { concepts explained by the professor. }\end{array}$ & $\begin{array}{l}\text { 1.Content retention } \\
\text { 2.Connections between the subjects } \\
\text { studied previously }\end{array}$ \\
\hline $\begin{array}{l}\text { RT 2: Making drawings in groups allows intense } \\
\text { knowledge sharing among the team members. }\end{array}$ & 3.Knowledge sharing \\
\hline $\begin{array}{l}\text { RT 3: Making drawings in groups is fun, fostering } \\
\text { creativity and communication skills }\end{array}$ & $\begin{array}{l}\text { 4.Fun activities } \\
\text { 5. Creativity } \\
\text { 6. Communication skills }\end{array}$ \\
\hline $\begin{array}{l}\text { RT4: Drawing in groups reduces the students' } \\
\text { boredom, makes the lecture more dynamic and } \\
\text { interesting. }\end{array}$ & 7. Students' boredom \\
\hline $\begin{array}{l}\text { RT 5: Drawing in groups helps students reinforce } \\
\text { their bonds. }\end{array}$ & 8. Students' bonds \\
\hline
\end{tabular}

\section{DISCUSSION}

RT1 and RT2 suggest that group drawing activities are fun activities that may lead to increased content retention, in knowledge sharing and in the connections the students make among the subjects studied previously. Our field observation reinforces this finding, it suggests that the majority of the groups ( $89 \%$ ) had high or moderate learning while performing the drawings in groups. More than that, the field observation also suggested that $78 \%$ of the groups worked in relaxed way, using humour in their drawings and in their activities. This finding is in accordance with the findings of Ainsworth et al. (2011) that states that drawing can help to combine previous knowledge with new knowledge. It is also aligned with the findings of other researchers (Garner, 
2006; Hill, 1988; Korobkin, 1988), who point out that humour in classrooms contributes to content retention and improves acquisition of knowledge.

RT3 suggest that group drawing activities allow students to exercise their creativity and develop communication skills. This finding is in accordance to Deiter (2000) who showed that amusing activities can reduce communication barriers.

Connecting the three aforementioned recurrent themes and the data from field observation, it seems that group drawing is an enjoyable activity that may contribute to the enhancement of the students' learning, which can improve their motivation to participate in other course activities (Figure 6, loop 'Students' learning').

RT4 suggests that the group drawing activities also reduces the students' boredom, increasing their motivation to participate (Figure 6, loops 'Students' interest' and 'Students' participation'). Our field observations related to participation and interest strengthens this finding, showing that $78 \%$ of the groups were highly interested in the activity and $78 \%$ participated intensively. This finding aligns with the findings of Chabeli (2008), who stated that humorous activities may reduce emotional strain and increase students' alertness.

RT5 suggests that group drawing activities helps to strengthen the connections between the team members, which in turn can impact positively on their motivation (Figure 6, loop 'Teamwork').

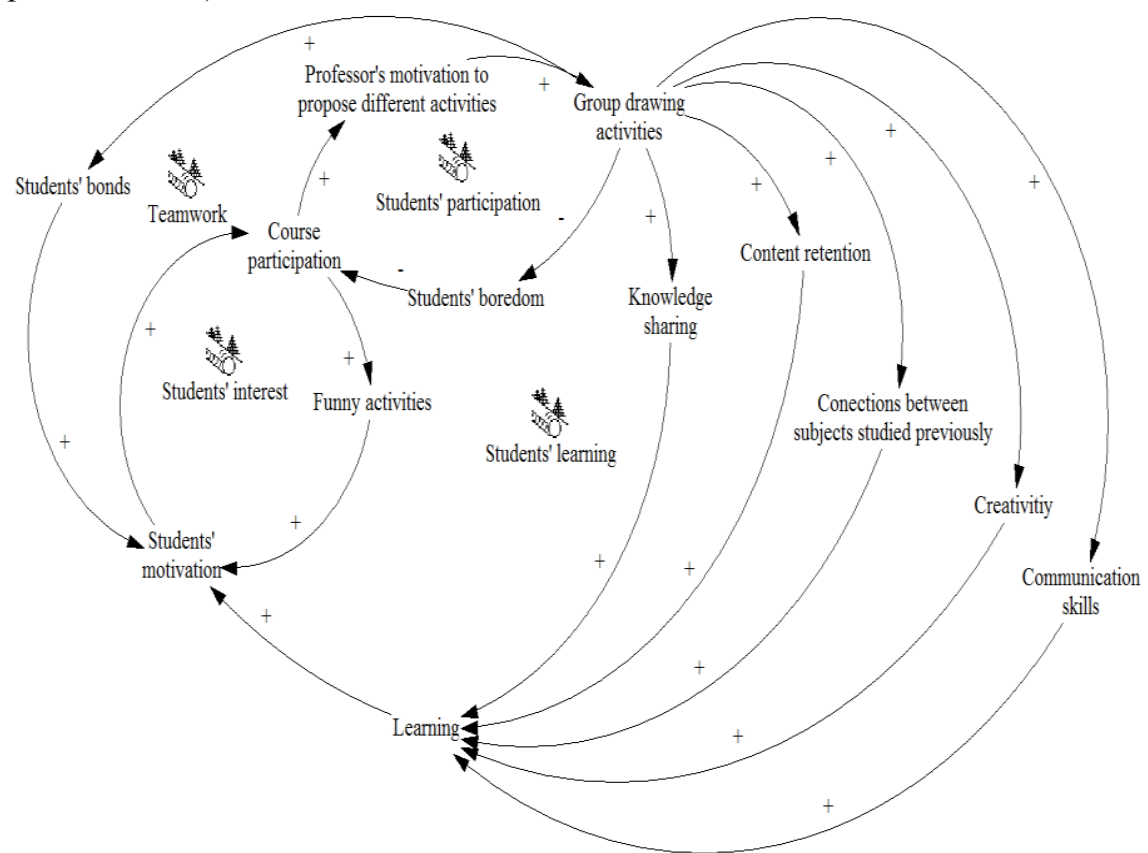

Figure 6

The dynamics that unfold as a result of the group drawing activity 


\section{CONCLUSION}

So, what did we learn from this experience?

Regarding our first research question (What are the impacts of the use of group drawing activities on students' participation?), we learned that group drawings activities, if accomplished in a humorous and relaxed way, may reduce the students' boredom and increase the students' motivation, therefore enhancing the students' willingness to participate in classroom activities.

Addressing the second research question (What are the impacts of the use of group drawing activities on students' learning?) we find that group drawing activities may facilitate the students to make connections between the theory and practice help the students to retain content and allow knowledge sharing. Therefore, we can say that group drawing activities can indeed contribute to learning improvement.

The drawings helped the students to understand that projects are systems and that managerial decisions can bring benefits in the short run but problems in the long run. When the students compared their drawing with the models developed by system dynamics experts, the students were able to see project dynamics that they had not been able to identify by themselves. Doing this exercise thus helps them to improve their mental models.

We can also affirm that our system analysis, combining data collected from the from focus group interviews with data collected from observation, facilitate the understanding of the systemic consequences of the use of this instructional technique.

Based on our study, we feel that the use of group drawing is useful educational technique and that bringing it into a Project Based Learning course can help the students connect theory with practice.

\section{REFERENCES}

Ainsworth, S., Prain, V., \& Tytler, R. (2011). Drawing to learn in science. Science, 333, 1096-1097.

Arantes do Amaral, J. A. (2012). Desvendando Sistemas [Unveiling Systems]. São Paulo: Editora Arantes

Arantes do Amaral, J. A., Gonçalves, P., \& Hess, A. (2015). Creating a project-based learning environment to improve project management skills of graduate students. Journal of Problem Based Learning in Higher Education, 3(2), 120-130.

Arantes do Amaral, J. A., \& Matsusaki, C. T. M. (2016). The dynamics of connecting universities, non-governmental organizations and community members by means of academic projects directed at people in need. Educational Action Research, 1-20.

Chabeli, M. (2008). Humor: A pedagogical tool to promote learning. Curationis, 31(3), 51-59.

Chan, Z. C. (2013). Drawing in nursing PBL. Nurse Education Today, 33(8), 818-822. 
Cook, C., \& Wind, Y. J. R. (2006). The power of impossible thinking: Transform the business of your life and the life of your business. New Jersey: Pearson Prentice Hall.

Cooper, K. G. (1980). Naval ship production: A claim settled and a framework built. Interfaces, 10(6), 20-36.

Cooper, K. G. (1993). The rework cycle: why projects are mismanaged. PM network, $7(2), 5-7$.

Creswell, J. W. (2013). Research design: Qualitative, quantitative, and mixed methods approaches. Thousand Oaks: Sage publications.

Deiter, R. (2000). The use of humor as a teaching tool in the college classroom. NACTA journal, 44(2), 20-27.

Forrester, J. W. (1971). Counterintuitive behavior of social systems. Theory and Decision, 2(2), 109-140.

Garner, R. L. (2006). Humor in pedagogy: How ha-ha can lead to aha! College Teaching, 54(1), 177-180.

Gray, C. F., \& Larson, E. W. (2002). Project management: The complete guide for every manager. New York: McGraw-Hill Professional.

Hill, D. J. (1988). Humor in the classroom: A handbook for teachers (and other entertainers!). Illinois: Charles C Thomas Publishing Ltd.

Korobkin, D. (1988). Humor in the classroom: Considerations and strategies. College Teaching, 36(4), 154-158.

Lyneis, J. M., \& Ford, D. N. (2007). System dynamics applied to project management: a survey, assessment, and directions for future research. System Dynamics Review, 23(2- 3), 157-189.

Meadows, D. H., \& Wright, D. (2008). Thinking in systems: A primer. White River Junction: Chelsea Green Publishing.

Musgrove, L. (2012). Handmade Thinking: A Picture Book on Reading and Drawing. San Angelo: CreateSpace.

Musgrove, L., \& Musgrove, M. (2015). Drawing is learning. The Journal of the Assembly for Expanded Perspectives on Learning, 20(1), 12.

Curry, L. (2016). Mixed Methods in Health Sciences Research: a Practical Primer. Thousand Oaks: Sage Publishing

PMBoK, A. (2000). Guide to the project Management body of knowledge. Newtown Square: Project Management Institute Inc.

Roam, D. (2013). The back of the napkin: Solving problems and selling ideas with pictures. New York: Penguim Group. 
Senge, P. (1990). The fifth discipline: The art and science of the learning organization. New York: Currency Doubleday.

Senge, P. M. (1992). Mental models. Planning review, 20(2), 4-44.

Sterman, J. D. (1992). System dynamics modeling for project management. Unpublished manuscript. Cambridge: Massachusetts Institute of Technology.

Sterman, J. D. (1994). Learning in and about complex systems. System Dynamics Review, 10(2), 291-330.

Sterman, J. D. (2002). All models are wrong: reflections on becoming a systems scientist. System Dynamics Review, 18(4), 501-531.

Stroh, D. P. (2015). Systems thinking for social change: A practical guide to solving complex problems, avoiding unintended consequences, and achieving lasting results. White River Junction: Chelsea Green Publishing.

Tang, J. C. (1991). Findings from observational studies of collaborative work. International Journal of Man-machine studies, 34(2), 143-160.

Williams, T. (2002). Modelling complex projects. West Sussex: Jon Wiley \& Sons, Ltd.

Yin, R. K. (2015). Qualitative research from start to finish. New York: The Guilford Press.

\section{Turkish Abstract}

Projeleri Sistemik Bakış Açısıyla Anlamayı Kolaylaştırmak için Grup Çizim Etkinliklerini Kullanmak

$\mathrm{Bu}$ makalede projeleri sistemik bakış açısıyla öğrenmeyi kolaylaştırmak için grup çizim etkinliğine ilişkin bulgular sunulmuştur. Yaklaşımı tartışmak için öğrencilerimizi ve ileri öğrenme sınıflarımızı kullandık. Grup çizim etkinliği projesini iki ayrı lisans sınıfında yürüttük. Bu sınıflar Brezilya'da bir devlet üniversitesi'nde 2016 yılında 2. dönem boyunca eğitim gören 41 öğrenciden oluşmaktadır. Araştırmamız nitel bir araştırma olup; nitel gözlem ve odak grup görüşmelerinden oluşmaktadır. Bu eğitim tekniğinin etkilerini ölçmek için gözlem notlarından elde edilen verilerin de analiz edildiği 5 kademeli nitel analiz yöntemi kullandık. Analizlerimiz sonucunda grup çizim etkinliğinin öğrencilerin ders içi faaliyetlere olan katılımını arttırdığ 1 öğrenciler arasındaki bağ 1 güçlendirdiği ve öğrenmeyi geliştirdiği yönünde olmuştur.

Anahtar Kelimeler: grup çizimi, sistemli düşünme, öğrenme, proje yönetimi, proje tabanli öğrenme

\section{French Abstract}

L'utilisation d'Activités de Dessins de Groupe pour Faciliter la Compréhension des Aspects Systémiques de Projets

Dans cet article, nous présentons nos découvertes quant à la promotion du groupe dessinant des activités pour faciliter l'apprentissage des aspects systémiques de projets. Nous discutons l'approche nous avons eu l'habitude d'engager les étudiants et favoriser l'apprentissage dans nos 
classes. Nous avons utilisé le groupe dessinant(tirant) des activités dans deux cours de licence de gestion de projet. Les cours, qui ont impliqué 41 étudiants, ont eu lieu pendant le deuxième semestre de 2016 dans une université publique au Brésil. Nous avons conduit la recherche qualitative, utilisant l'observation qualitative et des entretiens de groupe de discussion. Pour mesurer les effets de l'utilisation de cette technique éducative, nous avons suivi la méthode d'analyse qualitative à cinq de phase, combinée avec une analyse de systèmes des données obtenues de l'observation. Notre analyse de systèmes suggère que le dessin de groupe améliore la participation d'étudiant aux activités de salle de classe, renforce des liens entre les étudiants et améliore l'apprentissage.

Mots Clés: dessin de groupe, pensée de systèmes, apprentissage, gestion de projet, apprentissage à base de projet

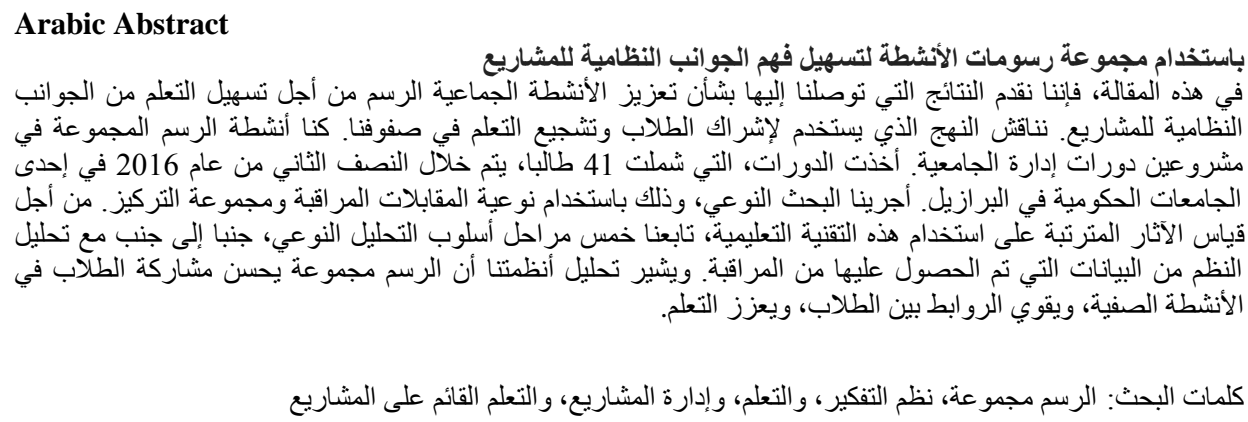

\section{German Abstract \\ Verwenden von Gruppenzeichnungen Aktivitäten zur Erleichterung des Verständnisses der systemischen Aspekte von Projekten}

In diesem Artikel stellen wir unsere Erkenntnisse zur Förderung von Gruppenzeichnungsaktivitäten vor, um das Lernen systemischer Aspekte von Projekten zu erleichtern. Wir diskutieren über die Herangehensweise, mit der wir die Studenten engagieren und das Lernen in unseren Klassen fördern. Wir verwendeten Gruppe Zeichnung Aktivitäten in zwei Projektmanagement Bachelor-Studiengänge. Die Kurse, an denen 41 Studenten teilnahmen, fanden im zweiten Semester 2016 in einer öffentlichen Universität in Brasilien statt. Wir führten qualitative Forschung mit qualitativen Beobachtungs und Fokusgruppen-Interviews durch. Um die Auswirkungen der Verwendung dieser pädagogischen Technik abzuschätzen, folgten wir der fünfphasigen qualitativen Analysemethode, kombiniert mit einer Systemanalyse der aus der Beobachtung gewonnenen Daten. Unsere Systemanalyse deutet darauf hin, dass die Gruppenzeichnung die Teilnahme der Schüler an Unterrichtsaktivitäten verbessert, die Bindungen zwischen den Studierenden stärkt und das Lernen verbessert.

Schlüsselwörter: gruppenzeichnung, systemdenken, lernen, projektmanagement, projektbasiertes lernen 


\begin{abstract}
Malaysian Abstract
Using Group Drawings Activities to Facilitate the Understanding of the Systemic Aspects of Projects

In this article, we present our findings regarding promoting group drawing activities in order to facilitate the learning of systemic aspects of projects. We discuss the approach we used to engage the students and foster learning in our classes. We used group drawing activities in two project management undergraduate courses. The courses, which involved 41 students, took place during the second semester of 2016 in a public university in Brazil. We conducted qualitative research, using qualitative observation and focus group interviews. In order to gauge the effects of the use of this educational technique, we followed the five-phased qualitative analysis method, combined with a systems analysis of the data obtained from observation. Our systems analysis suggests that group drawing improves student participation in classroom activities, strengthens bonds between students, and enhances learning.
\end{abstract}

Kata Kunci: group drawing, systems thinking, learning, project management, project-based learning

\title{
Russian Abstract \\ Использование Групповых Рисунков Деятельности для Облегчения Понимания Системных Аспектов Проектов
}

В этой статье, мы представляем наши выводы относительно внедрения опытной группы по рисованию. Для того, чтобы облегчить обучение в университете. Мы вовлекли студентов двух курсов и обучали в наших классах. В программу обучения мы внедрили групповые рисунки. Два курса- это 41 студент, которые обучались на втором семестре 2016 года в государственном университете в Бразилии. Мы провели качественные исследования, с использованием наблюдений и интервью фокус-групп. Для измерения изменений использовалась образовательная техника, мы следовали за пятью поэтапными качественными методами, в сочетании с системным анализом данных полученных из наблюдений. Из анализа следует, что групповой рисунок улучшает деятельность студентов в классе, укрепляет связи между студентами и повышает уровень обучение.

Ключевые Слова: группа рисунков, системное мышление, обучение, управление проектами, обучение на основе проектов 